\title{
Differences in Activities of Antioxidant Superoxide Dismutase, Glutathione Peroxidase and Prooxidant Xanthine Oxidoreductase/Xanthine Oxidase in the Normal Corneal Epithelium of Various Mammals
}

\author{
J. KOVAČEVA ${ }^{1}$, J. PLÁTENÍK ${ }^{2}$, M. VEJRAŽKA ${ }^{2}$, S. ŠTÍPEK ${ }^{2}$, T. ARDAN ${ }^{1}$, \\ Č. ČEJKA ${ }^{1}$, A. MIDELFART ${ }^{3}$, J. ČEJKOVÁ ${ }^{1}$ \\ ${ }^{1}$ Department of Eye Histochemistry, Institute of Experimental Medicine, Academy of Sciences of the \\ Czech Republic, Prague, ${ }^{2}$ Institute of Medical Biochemistry, First Faculty of Medicine, Charles \\ University, Prague, Czech Republic, ${ }^{3}$ Department of Ophthalmology, University Hospital, \\ Trondheim, Norway
}

Received October 27, 2005

Accepted January 31, 2006

On-line available February 23, 2006

\begin{abstract}
Summary
Under normal conditions, antioxidants at the corneal surface are balanced with the production of reactive oxygen species without any toxic effects. Danger from oxidative stress appears when natural antioxidants are overwhelmed leading to antioxidant/prooxidant imbalance. The aim of the present study was to examine the activities of enzymes contributing to the antioxidant/prooxidant balance in normal corneal epithelium of various mammals. The enzyme activities of antioxidant superoxide dismutase and glutathione peroxidase, as well as prooxidant xanthine oxidoreductase/xanthine oxidase were examined using biochemical methods. Results show that superoxide dismutase activity is high in rabbits and guinea pigs, whereas in pigs the activity is low and in cows it is nearly absent. In contrast, glutathione peroxidase activity is high in cows, pigs and rabbits, whereas in guinea pigs the activity is low. As far as prooxidant enzymes are concerned, elevated xanthine oxidoreductase/xanthine oxidase activities were found in rabbits, lower activities in guinea pigs, very low activity in cows and no activity in pigs. In conclusion, the above results demonstrate inter-species variations in activities of enzymes participating in antioxidant/prooxidant balance in the corneal epithelium. It is suggested that the levels of antioxidant and prooxidant enzymes studied in the corneal epithelium might be associated with the diurnal or nocturnal activity of animals. UV rays decompose hydrogen peroxide to damaging hydroxyl radicals and perhaps for this reason large animals with diurnal activity (cow, pig) require more effective peroxide removal (high glutathione peroxidase activity) together with the suppression of peroxide production (low superoxide dismutase activity, low xanthine oxidoreductase activity).
\end{abstract}

Key words

Mammals • Cornea $\bullet$ Epithelium • Antioxidants • Prooxidants 


\section{Introduction}

The cornea, together with the aqueous humor, protects the inner parts of the eye against the damaging effect of UV rays particularly of shorter wavelength (UVC, UVB), and the reactive oxygen species generated by them (e.g. Beak et al. 2004, Klamt et al. 2003). This is possible due to effective low-molecular weight antioxidants (such as ascorbic acid, glutathione, alphatocopherol) (e.g. Zhu and Crouch 1992, Ringvold 1988, Ringvold et al. 1988, Brubaker et al. 2000, Jo et al. 2002, Lee et al. 2002, Ayala and Soderberg, 2004) as well as high molecular weight antioxidants (such as superoxide dismutase, glutathione peroxidase and reductase, catalase) (reviewed by Čejková et al. 2004a). In the normal corneal epithelium, similarly as in other tissues (Halliwell 1991), the antioxidants are balanced with reactive oxygen species generation at a level at which these compounds can play their physiological roles without any toxic effects. Danger to the cornea from oxidative stress may appear when the corneal antioxidants are overwhelmed, leading to a prooxidant/antioxidant imbalance. This was observed after repeated irradiation of the cornea with UVB rays (Čejková et al. 2000, 2001). The activities of superoxide dismutase (an enzyme catalysing dismutation of superoxide to hydrogen peroxide and molecular oxygen) and glutathione peroxidase (an enzyme reducing hydrogen peroxide to water at the expense of reduced glutathione) were greatly decreased, whereas the activity of prooxidant xanthine oxidoreductase/xanthine oxidase (an enzyme known to generate reactive oxygen species) remained at normal levels or even increased. These changes could initiated oxidative eye injury (Čejková et al. 2000, 2001, 2004b, Tessem et al. 2004).

A prooxidant/antioxidant imbalance in the corneal epithelium after UVB ray exposure was found in rabbits, in which the activities of both antioxidant and prooxidant enzymes are relatively high in the normal corneal epithelium. In contrast to rabbits, little is known about the antioxidant/prooxidant balance in the corneal epithelium of other animal species, although antioxidant enzymes (not prooxidant ones) have been investigated in whole corneas using immunohistochemical as well as biochemical methods (for particular enzymes see Bhuyan and Bhuyan 1970, 1977, 1978, Crouch et al. 1984, Redmond et al. 1984, Rao et al. 1985, Atalla et al. 1987, 1988, 1990, Behndig et al. 1998, 2001, Yis et al. 2002, for review see Čejková et al. 2004a). Therefore, the aim of this study was to examine the activities of superoxide dismutase, glutathione peroxidase and xanthine oxidoreductase/xanthine oxidase in the scraped bovine, pig and guinea pig corneal epithelium and to compare activities of these enzymes with those in the rabbit corneal epithelium.

\section{Methods}

Animals

Bovine, pig, guinea pig and rabbit corneas of normal eyes were employed. The animals used for our experiments were on the same phase of their lifespan (1525-month-old cows, 6-month-old pigs, 6-month-old New Zealand white rabbits and 4-month-old guinea pigs). Corneas were examined immediately after the death of the animals.

For the biochemical examination of xanthine oxidoreductase/xanthine oxidase and antioxidant enzymes, the scraped corneal epithelium of individual animals was used.

All chemicals were obtained from normal commercial sources and were of at least analytical quality. Lglutathione (GSH), glutathione reductase from baker's yeast, tert-butyl hydroperoxide and nitroblue tetrazolium were purchased from Fluka. NADPH, EDTA, xanthine, xanthine oxidase, protease inhibitor cocktail, pterin (2amino-4-hydroxypteridine), isoxanthopterin (2-amino-4,7-dihydroxypteridine), allopurinol and buffers were purchased from Sigma.

\section{Preparation of tissue extract}

The corneal epithelium was scraped from individual eyes and homogenized in $1.2 \mathrm{ml}$ of deionized water $\left(4^{\circ} \mathrm{C}\right)$. Each cornea constituted one sample, only in experiments with guinea pigs, the epithelium from both eyes of the same animal was pooled. The glutathione peroxidase and superoxide dismutase assays were performed with aliquots of the fresh homogenate kept on ice. For the xanthine oxidoreductase assay, immediately after homogenization $100 \mu \mathrm{l}$ of the homogenate was added to $1 \mu \mathrm{l}$ of the protease inhibitor cocktail (Sigma); the mixture was rapidly frozen in $-20{ }^{\circ} \mathrm{C}$ ethanol and stored several weeks at $-85{ }^{\circ} \mathrm{C}$ until the assay was performed. The protein content was determined using the Biorad Protein Assay implemented to 96-well plates and calibrated to bovine serum albumin. Absorbances were read using a microplate reader Multiscan MS (Labsystems). 


\section{Glutathione peroxidase assay}

The activity of glutathione peroxidase was measured by the method of Beutler (1975). The glutathione peroxidase (GPX) of the sample catalyzed the oxidation of reduced glutathione (GSH) to GSSG by tertbutyl hydroperoxide. The rate of GSSG formation was then measured by means of the glutathione reductase reaction. NADPH reduces GSSG back to GSH in an excess of glutathione reductase. The rate of NADPH disappearance was followed at $340 \mathrm{~nm}$ for $20 \mathrm{~min}$ at $37^{\circ} \mathrm{C}$ using a spectrophotometer (Helios Alpha, Unicam). The reaction mixture contained $2 \mathrm{mM} \mathrm{GSH}$, $0.01 \%(\mathrm{v} / \mathrm{v})$ tert-butyl hydroperoxide, $1 \mathrm{U} / \mathrm{ml}$ glutathione reductase and $0.5 \mathrm{mM}$ EDTA in Tris- $\mathrm{HCl}$ buffer $(0.1 \mathrm{M}$, $\mathrm{pH}$ 8.0). The non-specific oxidation of NADPH was measured using two blanks. Blank 1 contained all the components mentioned above except the tissue homogenate and measured the non-enzyme-catalyzed oxidation of GSH. Blank 2 lacked tert-butyl hydroperoxide in order to control for other systems oxidizing NADPH in the sample.

\section{Superoxide dismutase assay}

The activity of superoxide dismutase was measured by a modified method of Sun et al. (1988) essentially as published previously (Štípek et al. 1995) with one new modification described below. Xanthine/xanthine oxidase system was employed as a source of superoxide, the substrate of superoxide dismutase, and nitroblue tetrazolium was used as an indicator of superoxide. $750 \mu \mathrm{l}$ of tissue extract was mixed with $600 \mu$ of ice-cold ethanol-chloroform mixture $(5: 3 \mathrm{v} / \mathrm{v})$ and immediately shaken on a Vortex for $20 \mathrm{~s}$. After $3 \mathrm{~min}$, the mixture was shaken for another $20 \mathrm{~s}$ and centrifuged at $2500 \mathrm{~g}$ for $45 \mathrm{~min}$ at $4{ }^{\circ} \mathrm{C}$. Supernatants were kept on ice. The supernatant (superoxide dismutase extract) was then mixed with phosphate buffer (50 mM, pH 7.8), EDTA (5 mM), bovine serum albumin (40 mg/l), nitroblue tetrazolium $(0.2 \mathrm{~g} / \mathrm{l})$, xanthine oxidase and xanthine $(0.1 \mathrm{mM})$. The absorbance at $546 \mathrm{~nm}$ was measured for $10 \mathrm{~min}$ at $25^{\circ} \mathrm{C}$. The activity of xanthine oxidase was adjusted to reach increase in absorbance of 0.1 units per $10 \mathrm{~min}$ in controls lacking superoxide dismutase activity. The inhibition of the xanthine oxidase reaction by sample was calibrated to commercial superoxide dismutase $(\mathrm{CuZn}$, bovine erythrocytes, Serva, $3125 \mathrm{U} / \mathrm{mg})$. Unlike all our measurements published previously (Štípek et al. 1995,
Čejková et al. 2000, 2004a,b), in this study calibration of our superoxide dismutase assay has been corrected for the inhibition of xanthine/xanthine oxidase system by ethanol used for enzyme extraction, leading to somewhat lower values of actual superoxide dismutase activities in rabbit corneas than reported previously.

\section{Xanthine oxidoreductase/xanthine oxidase assay}

The activity of xanthine oxidoreductase /xanthine oxidase was measured by a fluorimetric assay according to Hermes-Lima and Storey (1995), originally developed by Lowry (1957). The assay is based on enzymatic oxidation of pterin to isoxanthopterin; increase of the latter was monitored fluorometrically using excitation/emission wavelengths $350 \mathrm{~nm} / 390 \mathrm{~nm}$ at $25^{\circ} \mathrm{C}$ on spectrofluorometer Fluoromax-3 (Jobin Yvon, Inc.). Each sample was thawed immediately before addition to the spectrofluorometric cuvette containing potassium phosphate buffer $0.1 \mathrm{M} \mathrm{pH} \mathrm{7.6,} \mathrm{EDTA} 0.5 \mathrm{mM}$ and pterin $0.02 \mathrm{mM}$. Following sample addition, the isoxanthopterin production was measured for three minutes (assay for xanthine oxidase activity or $\mathrm{O}$ form of the enzyme). Next, methylene blue $(9.5 \mu \mathrm{M}$ final concentration) was added to the reaction mixture, and measurement of total xanthine oxidoreductase continued for further three minutes (both oxidase, $\mathrm{O}$ form, and dehydrogenase, $\mathrm{D}$ form, are measured under this condition). Finally, the enzyme was inhibited by allopurinol $(93 \mu \mathrm{M})$, and isoxanthopterin $(0.184 \mu \mathrm{M})$ was added to the mixture as an inner standard. Xanthine oxidoreductase and xanthine oxidase activities were calculated from the slopes of the kinetics obtained in the presence or absence of methylene blue, respectively, related to the fluorescence of isoxanthopterin addition, and expressed in nkat/g protein.

\section{Results}

The activity of antioxidant enzyme superoxide dismutase was rather high in the rabbit and guinea pig epithelium, much lower in the pig epithelium, and barely detectable in the bovine samples. In contrast, glutathione peroxidase activity was at the similar levels in the bovine, pig and rabbit corneal epithelium, but much lower in guinea pig epithelium (Fig. 1, Table 1).

The potentially prooxidant enzyme xanthine oxidoreductase activity was the highest in rabbit corneas, lower in guinea pigs, yet lower in cow samples, and it appeared totally absent from porcine corneal epithelium 
Table 1. Statistical analysis of biochemical data shown on Fig. 1 and 2.

\begin{tabular}{|c|c|c|c|c|c|}
\hline Comparison & $\begin{array}{l}\text { Superoxide } \\
\text { dismutase }\end{array}$ & $\begin{array}{l}\text { Glutathione } \\
\text { peroxidase }\end{array}$ & $\begin{array}{l}\text { Xanthine } \\
\text { oxidoreductase }\end{array}$ & $\begin{array}{l}\text { Xanthine } \\
\text { oxidase }\end{array}$ & $\begin{array}{l}\text { XOD in } \% \text { of } \\
\text { total XOR }\end{array}$ \\
\hline guinea pig vs. rabbit & NS & $\mathrm{NS}$ & $* * *$ & $* * *$ & NS \\
\hline guinea pig vs. pig & $*$ & NS & $* * *$ & $* *$ & - \\
\hline guinea pig vs. cow & $* *$ & $*$ & $*$ & NS & $* * *$ \\
\hline rabbit vs. pig & $* * *$ & NS & $* * *$ & $* * *$ & - \\
\hline rabbit vs. cow & $* * *$ & NS & $* * *$ & $* * *$ & $* * *$ \\
\hline pig vs. cow & NS & NS & NS & NS & - \\
\hline
\end{tabular}

The one-way ANOVA with Tukey-Kramer multiple comparison tests was calculated using GraphPad InStat software. NS - not significant, $* \mathrm{P}<0.05, * * \mathrm{P}<0.01, * * * \mathrm{P}<0.001$.

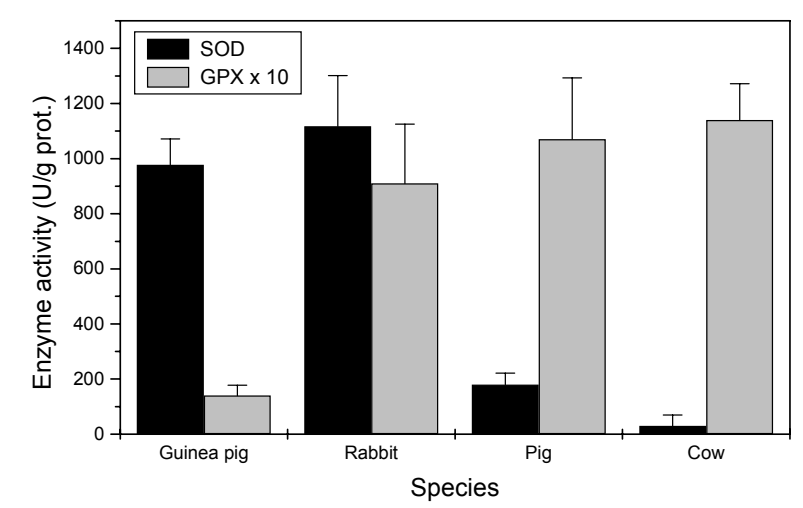

Fig. 1. Activities of antioxidant enzymes superoxide dismutase (SOD) and glutathione peroxidase (GPX) in the normal guinea pig, rabbit, pig, and cow corneal epithelium. The actual GPX activities have been multiplied by 10 to allow showing them on the same scale as SOD. All data are mean \pm SEM, for guinea pigs $n=4$ animals, for rabbits $n=12$ eyes, for pigs $n=8$ eyes, for cows $\mathrm{n}=8$ eyes. Statistical evaluation is summarized in Table 1.

(Fig. 2, Table 1). The relative fraction of the oxygen radicals-producing oxidase form of the enzyme was below $20 \%$ both in guinea pigs and in rabbits, but over $65 \%$ in bovine samples (Fig. 2, Inset).

In order to be sure that the absence of xanthine oxidoreductase from pig corneal epithelium is not due to freezing of the samples, one series of porcine samples was measured fresh up to $2 \mathrm{~h}$ from homogenization, with samples kept on ice in the presence of protease inhibitors until assayed. Yet another series of samples was subjected to $24 \mathrm{~h}$ of dialysis against the assay buffer to remove any low-molecular-weight inhibitors (Haining and Legan 1967) of the enzyme. However, neither of these variations in procedure led to the appearance of any measurable xanthine oxidoreductase activity in the

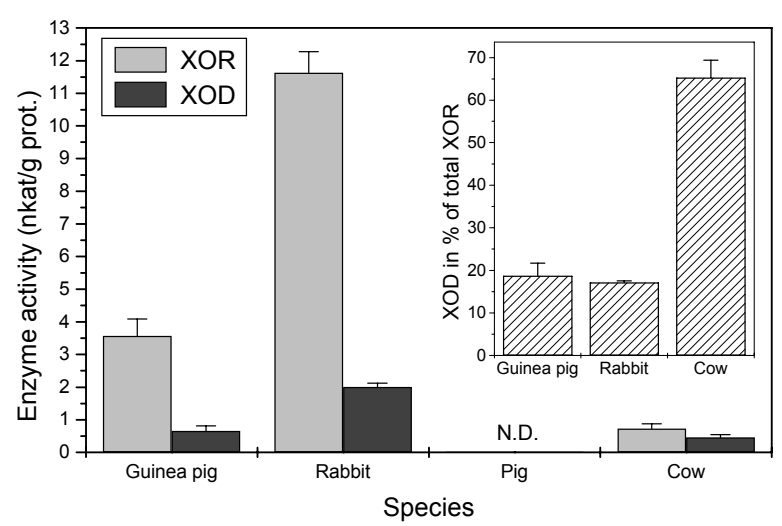

Fig. 2. The activities of xanthine oxidoreductase (XOR) and xanthine oxidase (XOD) in the normal guinea pig, rabbit, pig, and cow corneal epithelium. The inset shows the same data for XOD expressed in per cent of total xanthine oxidoreductase activity. All data are mean \pm SEM, for guinea pigs $n=9$ animals (for XOD 7 animals), for rabbits $n=24$ eyes, for pigs $n=18$ eyes, for cows $\mathrm{n}=8$ eyes. N.D. not detected, means the activity is below the detection limit of our XOR assay $(<0.08 \mathrm{nkat} / \mathrm{g}$ protein for pig corneal epithelium samples). Statistical evaluation is summarized in Table 1.

porcine samples.

\section{Discussion}

The effective antioxidant defense requires concerted actions of both superoxide dismutase (producing hydrogen peroxide from superoxide) and glutathione peroxidase (removing the hydrogen peroxide). This also holds true for corneal epithelium of all the mammalian species we have examined. Nevertheless, our data suggest a quite interesting general inverse relationship between the ratio of superoxide dismutase (peroxide-producing) to glutathione peroxidase (peroxide-removing) and size of the animal/preference of diurnal activity: the superoxide dismutase/glutathione 
peroxidase ratio is 69.8 in guinea pigs, 12.3 in rabbits, 1.7 in pigs and 0.26 in cows. Ultraviolet light is well-known to decompose (photolyse) hydrogen peroxide to damaging hydroxyl radicals (e.g. Goldstein et al. 1993). Perhaps for that reason the antioxidant protection of the eye in large animals with diurnal activity (cow, pig) requires more efficient peroxide removal together with relative suppression of peroxide production, compared to a small mammal with predominant nocturnal activity, such as guinea pig. In this connection it must be pointed out that very similar results were obtained with ascorbate concentration by Reiss et al. (1986) in the aqueous humor and by Ringvold et al.(1998) in the corneal epithelium. Ascorbate levels were higher in diurnal animals than in nocturnal species. Ringvold et al. (2003) examined in various mammals, whether the content of ascorbic acid in the corneal epithelium and the epithelial thickness might be influenced by environmental change. Results showed that radiation was needed to sustain a high ascorbic acid concentration in the corneal epithelium. Also, corneal epithelial thickness and number of cells were regulated by radiation. The authors suggested that seasonal adaptation of mammalian corneal epithelium in response to radiation may be natural strategy for countering radiation damage to the eye. In contrast to these studies showing that the concentrations of low-molecular weight as well as high-molecular weight antioxidants can differ in dependence on diurnal or nocturnal activity of animals, information about the effect of housing or lighting on the level of antioxidants is lacking. Furthermore, no data are available whether the levels of antioxidants in nocturnal animals (or diurnal animals) can be changed by housing under lightened conditions (or by housing under dark conditions) and how rapid might be the adaptive response. Further studies are necessary in this field.

Comparing the activities of prooxidant enzymes (xanthine oxidoreductase/xanthine oxidase) in the rabbit corneal epithelium with the same enzymes in the corneal epithelium of other animals, the activity of xanthine oxidoreductase is low in the guinea pig corneal epithelium, very low in the bovine epithelium and absent in the pig corneal epithelium. The ratio of xanthine oxidase, an enzyme known to generate reactive oxygen species, to total xanthine oxidoreductase is approximately $20 \%$ in the rabbit and guinea pig corneal epithelium, whereas in the bovine corneal epithelium the xanthine oxidase ratio is much higher $(65 \%)$. Thus, even if the xanthine oxidase ratio is relatively high in the bovine corneal epithelium, the activity of the whole enzyme (xanthine oxidoreductase) is very low and therefore certain correlation can be seen between the inter-species differences in expression of this enzyme activity and the antioxidant enzymes superoxide dismutase and glutathione peroxidase discussed above. A particularly intriguing finding is the apparent absence of xanthine oxidoreductase from the pig corneal epithelium. In fact, it contradicts our previous histochemical and immunohistochemical studies on xanthine oxidoreductase/xanthine oxidase in various animal species where some staining was present in the pig corneal epithelium (Ardan et al. 2004). Methodological differences can be considered to account for this discrepancy: the histochemical technique uses hypoxanthine (the natural substrate for xanthine oxidoreductase), while the fluorometric assay is based on oxidation of a pteridine derivative, for which certainly the enzyme Michaelis constant is at least one order higher than for hypoxanthine. However, it is also possible that the pig has lower expression of this enzyme in general. Janssen et al. (1993) measured the xanthine oxidoreductase in the heart of various mammalian species, and they found the activity less than $1.5 \mathrm{mU} / \mathrm{g}$ protein in the pig heart, while in the rat heart it was $470 \mathrm{mU} / \mathrm{g}$ protein, in the guinea pig heart $270 \mathrm{mU} / \mathrm{g}$ protein, and human heart $5.4 \mathrm{mU} / \mathrm{g}$ protein.

Summarizing the results of this study, striking differences in the activities of antioxidant and prooxidant enzymes were found in the corneal epithelium of various mammals. As described previously in rabbits, the activities of antioxidant enzymes (but not prooxidant enzymes) are highly dependent on the age of the animals. Antioxidant enzyme activity dramatically decreases in aged corneas (Čejková et al. 2004b). Therefore, in this study young adult animals were employed (not aged animals) and thus the results should not be influenced by the age of animals. The differences in enzyme activities among the animals examined might implicate their different susceptibility to oxidative stress. However, it must be mentioned that in addition to superoxide dismutase and glutathione peroxidase, several other antioxidants exist that protect the corneal epithelium against oxidative stress. Of the enzymatic antioxidants, catalase protects ocular tissues against hydrogen peroxide and also protects superoxide dismutase from inactivation by hydrogen peroxide (reviewed by Čejková et al. 2004b), while $\mathrm{NADP}^{+}{ }_{-}$dependent isocitrate dehydrogenase, a bovine crystallin, protects against UVinduced injury by preventing lipid peroxidation (Sun et 
al. 1999), protein oxidation, oxidative DNA damage, and intracellular peroxide generation (Jo et al. 2002, Lee et al. 2002). Cytosolic aldehyde dehydrogenase 3A1, the major water-soluble protein in the mammalian cornea, is also a very important corneal antioxidant enzyme (Abedinia et al. 1990, Pappa et al. 2001, Piatigorski 2001). According to Pappa et al. (2003), this enzyme has several postulated defense functions protecting the corneal epithelium against UV-induced oxidative damage, including the detoxification of peroxidic aldehydes, the scavenging of free radicals, and the direct absorption of ultraviolet (UV) radiation. Among nonenzymatic antioxidants, ascorbate plays a key role. As described by Ringvold (1998), the corneal epithelium absorbs UV-B radiation mainly owing to its ascorbate content. According to this author, the corneal epithelium acts as a UV-filter, protecting the internal structures through three different mechanisms: the absorption of UV-B roughly below $310 \mathrm{~nm}$ wavelengths, fluorescencemediated ray transformation to longer wavelength and fluorescence reduction. Brubaker et al. (2000) measured the concentration of ascorbic acid in the human corneal epithelium and suggested that a high ascorbate content can protect the basal layer of the epithelium by absorption of incident ultraviolet radiation. Vitamin E protects the cornea directly as an antioxidant and/or indirectly through increased levels of glutathione (Ayala and Soderberg 2004). Albumin, a corneal protein, acts as an anti-oxidant by scavenging hydrogen peroxide (Zhu and Crouch 1992).

In conclusion, beside enzymes examined in this study, also other factors are involved in antioxidant/prooxidant balance in the corneal epithelium. Based on the results of this study, we suggest that enzymatic generation and cleavage of reactive oxygen species in the corneal epithelium of large animals (cow, pig) with diurnal activity and small animal (guinea pig) with nocturnal activity differ in accordance with radiation (UV) exposure.

\section{Acknowledgements}

This study was supported by a grant from the Grant Agency of the Czech Republic No. 304/06/1379 and a grant from the Academy of Sciences of the Czech Republic AV0Z 50390512. Help of Mgr. Richard Buchal and Ing. Jarmila Lakomá is acknowledged.

\section{References}

ABEDINIA M, PAIN T, ALGAR EM, HOLMES RS: Bovine corneal aldehyde dehydrogenase: the major soluble protein with a possible dual protective role for the eye. Exp Eye Res 51: 419-426, 1990.

ARDAN T, KOVAČEVA J, ČEJKOVÁ J: Comparative histochemical and immunohistochemical study on xanthine oxidoreductase/xanthine oxidase in mammalian corneal epithelium. Acta Histochem 106: 69-71, 2004.

ATALLA LR, FERNANDEZ MA, RAO NA: Immunohistochemical localization of catalase in ocular tissue. Curr Eye Res 7: 1181-1187, 1987.

ATALLA LR, SEAVANIAN A, RAO NA: Immunohistochemical localization of glutathione peroxidase in ocular tissues. Curr Eye Res 7: 1023-1027, 1988.

ATALLA LR, SEVANIAN A, RAO NA: Immunohistochemical localization of peroxidative enzymes in ocular tissues. CLAO J 16 (Suppl): S30-S33, 1990.

AYALA MN, SODERBERG PG: Vitamin E can protect against ultraviolet radiation-induced cataract in albino rats. Ophthalmic Res 36: 264-269, 2004.

BEAK SM, LEE YS, KIM JA: NADPH oxidase and cyclooxygenase mediate the ultraviolet B-induced generation of reactive oxygen species and activation of nuclear factor- $\kappa \mathrm{B}$ in HaCaT human keratinocytes. Biochimie 86: 425 429, 2004.

BEHNDIG A, SVENSSON B, MARKLUND SL, KARLSSON K: Superoxide dismutase isoenzymes in the human eye. Invest Ophthalmol Vis Sci 39: 471-475, 1998.

BEHNDIG A, KARLSSON K, JOHANSSON BO, BRANNSTROM T, MARKLUND SL: Superoxide dismutase isoenzymes in the normal and diseased human cornea. Invest. Ophthalmol Vis Sci 42: 2293-2296, 2001.

BEUTLER E: Red cell metabolism. In: A Manual of Biochemical Methods. Grune \& Stratton, New York, 1975, pp 71-73.

BHUYAN KC, BHUYAN DK: Catalase in ocular tissue and its intracellular distribution in corneal epithelium. Am $J$ Ophthalmol 69: 147-153, 1970. 
BHUYAN KC, BHUYAN DK: Regulation of hydrogen peroxide in eye humors. Effect of 3-amino-1H-1,2,4-triazole on catalase and glutathione peroxidase of rabbit eye. Biochim Biophys Acta 497: 641-651, 1977.

BHUYAN KC, BHUYAN DK: Superoxide dismutase of the eye: relative functions of superoxide dismutase and catalase in protecting the ocular lens from oxidative damage. Biochim Biophys Acta 542: 28-38, 1978.

BRUBAKER RF, BOURNE WM, BACHMAN LA, MCLAREN JW: Ascorbic acid content of human corneal epithelium. Invest Ophthalmol Vis Sci 41: 1681-1683, 2000.

ČEJKOVÁ J, ŠTIIPEK S, CRKOVSKÁ J, ARDAN T: Changes of antioxidant enzymes in the cornea of albino rabbits irradiated with UVB rays. Histochemical and biochemical study. Histol Histopathol 15: 1043-1050, 2000.

ČEJKOVÁ J, ŠTÍPEK S, CRKOVSKÁ J, ARDAN T, MIDELFART A: Reactive oxygen species (ROS)-generating oxidases in the normal rabbit cornea and their involvement in the corneal damage evoked by UVB rays. Histol Histopathol 16: 523-533, 2001.

ČEJKOVÁ J, ŠTÍPEK S, CRKOVSKÁ J, ARDAN T, PLÁTENÍK J, ČEJKA Č, MIDELFART A: UV rays, the prooxidant/antioxidant imbalance in the cornea and oxidative eye damage. Physiol Res 53: 1-10, 2004a.

ČEJKOVÁ J, VEJRAŽKA M, PLÁTENÍK J, ŠTÍPEK S: Age-related changes in superoxide dismutase, glutathione peroxidase, catalase and xanthine oxidoreductase/xanthine oxidase activities in the rabbit cornea. Exp Gerontol 39: 1537-1543, 2004b.

CROUCH RK, PATRICK J, GOOSEY J, COLES WH: The effect of age on corneal and lens superoxide dismutase. Curr Eye Res 3: 1119-1123, 1984.

GOLDSTEIN S, MEYERSTEIN D, CZAPSKI G: The Fenton reagents. Free Rad Biol Med 15: 435-445, 1993.

HAINING JL, LEGAN JS: Fluorometric assay for xanthine oxidase. Anal Biochem 21: 337-343, 1967.

HALLIWELL B: Reactive oxygen species in living systems: source, biochemistry and role of human disease. Am J Med 91 (Suppl. 3C): 14S-22S, 1991.

HERMES-LIMA M, STOREY KB: Xanthine oxidase and xanthine dehydrogenase from an estivating land snail. Z Naturforsch 50: 675-694, 1995.

JANSSEN M, VAN DER MEER P, DE JONG JW: Antioxidant defences in rat, pig. guinea pig, and human hearts: comparison with xanthine oxidoreductase activity. Cardiovasc Res 27: 2052-2057, 1993.

JO SH, LEE SH, CHUN HS, LEE SM, KOH HJ, LEE SE, CHUN JS, PARK JW, HUH TL: Cellular defence against UVB-induced phototoxicity by cytosolic NADP(+)-dependent isocitrate dehydrogenase. Biochem Biophys Res Commun 292: 542-549, 2002.

KLAMT F, DAL-PIZZOL F, BERNARD EA, MOREIRA JC: Enhanced UV-mediated free radical generation; DNA and mitochondrial damage caused by retinol supplementation. Photochem Photobiol Sci 2: 856-860, 2003.

LEE SM, KOH HJ, PARK DC, SONG BJ, HUH TL, PARK JW: Cytosolic NADP(+)-dependent isocitrate dehydrogenase status modulates oxidative damage to cells. Free Radic Biol Med 32: 1185-1196, 2002.

LOWRY OH: Micromethods for the assay of enzymes. Meth Enzymol 4: 366-381, 1957.

PAPPA A, SOPHOS NA, VASILIOU V: Corneal and stomach expression of aldehyde dehydrogenases: from fish to mammals. Chem Biol Interact 130-132: 181-191, 2001.

PAPPA A, ESTEY T, MANZER R, BROWN D, VASILIOU V: Human aldehyde dehydrogenase 3A1 (ALDH3A1): biochemical characterization and immunohistochemical localization in the cornea. Biochem J 376: 615-623, 2003.

PIATIGORSKY J: Enigma of the abundant water-soluble cytoplasmic proteins of the cornea: the "refracton" hypothesis. Cornea 20: 853-858, 2001.

RAO NA, THAETE LG, DELMAGE JM, SEVANIAN A: Superoxide dismutase in ocular structures. Invest. Ophthalmol Vis Sci 26: 1778-1781, 1985.

REDMOND TM, DUKE EJ, COLES WH, SIMSON JA, CROUCH RK: Localization of corneal superoxide dismutase by biochemical and histocytochemical techniques. Exp Eye Res 38: 369-378, 1984.

REISS GR, WERNESS PG, ZOLLMAN PE, BRUBAKER RF: Ascorbic acid levels in the aqueous humor of nocturnal and diurnal animals. Arch Ophthalmol 104: 753-755, 1986.

RINGVOLD A: Corneal epithelium and UV-protection of the eye. Acta Ophthalmol Scand 76: 149-153, 1998. 
RINGVOLD A, ANDERSSEN E, KJONNIKSEN I: Ascorbate in the corneal epithelium of diurnal and nocturnal species. Invest Ophthalmol Vis Sci 39: 2774-2777, 1998.

RINGVOLD A, ANDERSSEN E, KJONNIKSEN I: Impact of the environment on the mammalian corneal epithelium. Invest Ophthalmol Vis Sci 44: 10-15, 2003.

ŠTÍPEK S, CRKOVSKÁ J, DVOŘÁK V: Spectrophotometric assay for superoxide dismutase controlled by PCprogramme developed in LabWindows system. Klin Biochem Metab 3: 93-97, 1995.

SUN Y, OBERLEY LW, LI Y: A simple method for clinical assay of superoxide dismutase. Clin Chem 34: 497-500, 1988.

SUN L, SUN T, LAVKER RM: Identification of a cytosolic $\mathrm{NADP}^{+}$-dependent isocitrate dehydrogenase that is preferentially expressed in bovine corneal epithelium. A corneal epithelial crystallin. J Biol Chem 274: 1733417341, 1999.

TESSEM MB, BATHEN TF, ČEJKOVÁ J, MIDELFART A: Effect of UV-AA and UV-B irradiation on the metabolic profile of aqueous humor in rabbits analyzed by 1H NMR Spectroscopy. Invest Ophthalmol Vis Sci 46: 776781, 2004.

YIS O, BILGIHAN A, BILGIHAN K, YIS NS, HASANREISOGLU B: The effect of excimer laser keratectomy on corneal glutathione peroxidase activities and aqueous humor selenium levels in rabbits. Graefes Arch Clin Exp Ophthalmol 240: 499-502, 2002.

ZHU L, CROUCH RK: Albumin in the cornea is oxidized by hydrogen peroxide. Cornea 11: 567-572, 1992.

\section{Reprint requests}

J. Čejková, Department of Eye Histochemistry and Pharmacology, Institute of Experimental Medicine, Academy of Sciences of the Czech Republic, Vídeňská 1083, 142 20, Prague 4, Czech Republic. Fax: (4202) 41062692. E-mail: cejkova@biomed.cas.cz. 